\title{
A informação de moda sem gênero nas mídias sociais: o sujeito contemporâneo enquanto agente no processo de construção do vestuário
}

The information of fashion without gender in social media: the contemporary subject as agent in the process of construction of clothing

\author{
Leite, Iracema Tatiana Ribeiro \& Waechter, Hans
}

Informação de moda, mídias sociais, gênero

\begin{abstract}
O presente artigo tem o objetivo apresentar as mídias sociais como fonte de informação e disseminação da moda sem gênero, trazendo o olhar para o Instagram como objeto de estudo para construção e manifestações das identidades de gênero representadas através do vestuário. A metodologia utilizada é a pesquisa qualitativa, utilizando-se o hashtag (\#) como ferramenta de busca de imagens para comunicação de moda. As imagens apresentadas são descritas observando-se o conteúdo de moda e as configurações da linguagem visual e verbal, traçando em paralelo com as teorias de gênero e alguns autores que se debruçam para contribuir para as pesquisas de moda e as construções das identidades. $O$ resultado da pesquisa traz a teoria da Performatividade proposta por Judith Butler como base para se compreender os simbolismos da relação da roupa com a construção do sujeito, mostrando não apenas a relação das marcas de moda e consumo, mas também as trocas simbólicas existentes entre as marcas e os usuários que as seguem.
\end{abstract}

Fashion information, social media, gender

This article aims to present social media as a source of information and dissemination of fashion without gender, bringing the Instagram as an object of study for the construction and manifestations of gender identities represented through clothing. The methodology used is qualitative research, using hashtag (\#) as a tool for searching images for fashion communication. The images presented are described by observing the fashionable content and verbal and visual language settings, drawing in parallel with gender theories and some authors who focus on contributing to fashion research and identity constructions. The result of the research brings the theory of Performativity proposed by Judith Butler as a basis for understanding the symbolism of the relation of clothes to the construction of the subject, showing not only the relation of fashion brands and consumption, but also the symbolic exchanges between the brands and the users who follow them.

\section{Introdução}

A relação do vestuário com o corpo é uma das formas de identificação dos sujeitos para representar sua identidade social e de gênero, e atualmente tem-se observado novas formas de apresentação da roupa, sem que necessariamente haja uma relação figurativa dela com o corpo biológico ou natural. Essa "nova roupa" é nomeada no cenário da Moda como Moda sem gênero, moda não binária, plurissex, Agender, Genderless, no gender. Esta tendência de moda traz a atenção não mais a biologia para se pensar as identidades, apresentando também novos experimentos dos corpos e as roupas, que segundo Zambrini (2016, p. 58) a tendência das lojas "a-gender" ou "no gender"(sem gênero) são propostas do vestir que expressam o câmbio social em relação às novas maneiras de entender os gêneros, os corpos e as identidades sociais.

Neste contexto, estas propostas do vestir têm sido ressaltadas na contemporaneidade, principalmente nos meios de socialização via internet, como blogs de moda, sites de conteúdo de moda e redes sociais e refletem sobre as novas configurações do vestir, revisitando a

Anais do 9 CIDI e 9 CONGIC

Luciane Maria Fadel, Carla Spinillo, Anderson Horta, Cristina Portugal (orgs.)

Sociedade Brasileira de Design da Informação - SBDI

Belo Horizonte | Brasil | 2019

ISBN 978-85-212-1728-2
Proceedings of the 9th CIDI and 9th CONGIC

Luciane Maria Fadel, Carla Spinillo, Anderson Horta, Cristina Portugal (orgs.)

Sociedade Brasileira de Design da Informação - SBDI

Belo Horizonte | Brazil | 2019

ISBN 978-85-212-1728-2 
história da moda e suas tentativas de apresentar novas significações além da relação binária feminino e masculino.

O estudo com o usuário é uma das informações centrais para o processo de design de moda, e atualmente observa-se as mídias sociais para traçar como alguns grupos de pessoas pensam sobre determinado assunto e produto, o que reflete no entendimento para a construção de produtos de moda.

A presente proposta está em apresentar uma revisão bibliográfica apresentando as fronteiras de gênero no vestir, observando a informação de moda sem gênero e suas representações visuais, utilizando como objeto de estudo as imagens de roupas sem gênero apresentadas no instagram.

O instagram é bastante utilizado para traçar determinado perfil e estilo de vida de determinado sujeito ou grupo e é utilizado no processo de design, aproximando as marcas aos usuários, onde os mesmos tem liberdade de opinião sobre determinado assunto ou produto. Segundo Demezio etc al (2016, p.2) "A partir de recursos como Storytelling (capacidade de contar histórias relevantes por meio de palavras ou recursos audiovisuais) e Hashtags (palavras-chave usadas seguidamente do símbolo \#, que funcionam como marcações de assuntos para buscas posteriores) as marcas conseguem conquistar os usuários, pois os aproximam da mesma ". Outro fator importante em relação a rede social Instagram é que além desta aproximação das marcas e os usuários, o próprio usuário participa do processo de criação dos produtos, que segundo Cazorla e Noronha (2015, p. 17) "Ao dispor desses recursos, o usuário do aplicativo Instagram registra a si próprio, torna-se cúmplice na produção de crenças e passa a ser também dotado da capacidade de transformação lúdica dos objetos."

A partir do problema de pesquisa: "Como o sujeito contemporâneo pode comunicar aspectos relacionados as fronteiras de gênero para o processo de criação do design de moda sem gênero?", pretende-se apresentar as mídias sociais em sua relação com as identidades de gênero, direcionado para as pesquisas no campo do design de moda, utilizando a observação das imagens contidas no Instagram.

\section{Metodologia}

A metodologia de pesquisa utilizada é a Revisão bibliográfica, método Exploratório e Pesquisa Qualitativa. A presente pesquisa tem como principal recorte metodológico a observação das pesquisas sobre Moda sem gênero na perspectiva das teorias contemporâneas de gênero e design de moda. Pretende-se explorar bibliograficamente essas teorias e apresentar como campo de pesquisa a mídia social Instagram.

As etapas realizadas estão propostas da seguinte forma:

Fase 1- Levantamento bibliográfico sobre o design de moda e as fronteiras de gênero

Fase 2- Observar as publicações sobre moda agênero, sem gênero ou genderless no Instagram através do hashtags (\#modasemgenero) analisando as linguagens visuais adotadas e as informações de conteúdo de moda atreladas às mesmas.

Fase 3: Cruzar as informações, teorias e conceitos com as imagens levantadas no Instagram.

\section{A teoria da performatividade e suas implicações no sujeito contemporâneo}

Os conceitos relacionados ao sujeito contemporâneo têm como temática de pesquisa as identidades. Com o advento da internet, e mais significamente com as mídias sociais, vê-se uma preocupação de se compreender as identidades de gênero. Uma das autoras que ganhou expressão nestes conceitos relacionados a gênero é Judith Butler, cujas pesquisas estão em torno desta reflexão da identidade de gênero vir antes do nascimento do sujeito, ou seja, numa visão de que os seres são guiados e coordenados para exercer determinadas identidades de 
acordo com a cultura e a sociedade ao qual estão inseridos. Silva (2018, s.p ) afirma que "Butler vai perceber que os recortes de gênero opera identificando seres humanos à mesma maneira que identificamos objetos: pela aparência."

Neste sentido, quem não estiver inserido no modelo padrão hegemônico de gênero se sente deslocado da sociedade, Butler (2004) critica esta relação do gênero e identidade afirmando que:

(...) a "unidade" do gênero é um efeito de uma prática reguladora que busca uniformizar a identidade de gênero por via da heterossexualidade compulsória. A força dessa prática é mediante um aparelho de produção excludente, restringir os significados relativos de "heterossexualidade", "homossexualidade" e " bissexualidade", bem como os lugares subversivo de sua convergência e resignificação. (Butler, 2004, p. 57)

$\mathrm{Na}$ contemporaneidade, o limite de sexo/gênero vem sendo explicitamente criticado nas redes sociais, e estes atos estão gerando uma série de reflexões não só academicamente como entre os próprios sujeitos. A binaridade masculino e feminino é uma das críticas levantadas pelos teóricos e pessoas que não se sentem inseridas neste modelo. Butler (2018) discerne que:

Os limites da análise discursiva do gênero pressupõem e definem por antecipação as possibilidades das configurações imagináveis e realizáveis do gênero na cultura. Isso não quer dizer que toda e qualquer possibilidade de gênero seja facultada, mas que as fronteiras analíticas sugerem os limites de uma experiência discursivamente condicionada. (Butler, 2018, p. 28)

Estes limites discursivos de gênero são normas culturais estabelecidas pelo poder hegemônico e heteronormativo ao qual as sociedades são condicionadas desde tempos remotos. As identidades de gênero que não estejam neste limite que naturaliza o gênero conforme o sexo biológico não são incluídas por não serem "inteligíveis" perante aos atributos construídos culturalmente, onde a binaridade feminino e masculino são regidas por seus corpos.

Silva (2018) destaca: "Butler questiona que gênero é somente o desempenho repetido de comportamentos, e esta repetição ao longo do tempo é o que produz a ficção do que as identidades de gênero devem ser."

Uma das reflexões que Butler (2018) contextualiza em seu livro: Problemas de gênero: feminismo e subversão da identidade são as estruturas internas e externas dos corpos que são moldadas pela cultura, o que ela chama de "Performance do corpo", e cita o travestismo cujos atos e representações brincam com estas estruturas, corpo biológico (interno) corpo representacional (externo).

Neste sentido as performances do corpo, a partir de atos repetitivos e representacional do corpo interno e externo é encenado continuamente na sociedade e internalizado como uma crença, transformando em substância, essência.

Portanto para Butler (2018):

O fato de a realidade do gênero ser criada mediante performances sociais contínuas significa que as próprias noções de sexo essencial e de masculinidade ou feminilidade verdadeiras ou permanentes também são constituídas, como parte da estratégia que oculta o caráter performativo do gênero e as possibilidades performativas de proliferação das configurações de gênero fora das estruturas restritivas da dominação masculinista e da heterossexualidade compulsória. (Butler, 2018, p. 201).

As noções em volta a performatividade de gênero vão de encontro a fluidez das identidades sociais e de gênero, e as oscilações entre imitação e distinção ao longo da história da humanidade que inclui atos de aceitação dos sujeitos pelos outros, são parte de uma sociedade reguladora englobada por uma totalidade hegemônica regidos por interesses políticos, econômicos, sociais, dentre outros.

A teoria da performatividade vista por Butler é uma forte reflexão sobre o sujeito contemporâneo e a formação da identidade, que não é fixa, que está em construção, não está finalizada. Segundo Salih (2015, p. 11) O "sujeito" de Butler não é um indivíduo, mas uma 
estrutura linguística em formação. A "sujeitidade" [" subjecthood"] não é um dado, e, uma vez que o sujeito está sempre envolvido num processo de devir sem fim, é possível reassumir ou repetir a sujeitidade de diferentes maneiras." Ainda segundo a mesma autora (2015, p. 89): “

Butler desfaz a distinção sexo/ gênero para argumentar que não há sexo que não seja já e, desde sempre, gênero. Todos os corpos são "generificados" desde o começo de sua existência social (e não há existência que não seja social), o que significa que não há "corpo natural" que preexista à sua inscrição cultural."

Esta busca dos sujeitos em se localizar enquanto ser no mundo ao qual está inserido, geram uma série de discursos e utilizam as diversas representações que exteriorizem sua posição na sociedade, e a moda neste sentido, ajuda os sujeitos a se expressarem a partir de uma linguagem visual e verbal, pela roupa, pelos discursos, pelos gestos e atitudes.

Muitos estudiosos das teorias de gênero interpretam e colocam os posicionamentos de Judith Butler para as questões relacionadas a teoria da performatividade, e neste sentido, é notório a localização deste pensamento voltado para a não binaridade feminina e masculina que deve ser objeto de reflexão e compreensão, para se compreender como funciona as formas de presentificação dos sujeitos no mundo, extenuadas a partir de diferentes contextos e formas, e uma delas é através da moda.

\section{Instagram como ferramenta para legitimação da moda sem gênero- Usuário e marcas de moda}

A tendência da moda sem gênero vem sido apresentada nos meios de informação de moda por volta dos anos 2009, com propostas que vão além da moda Unissex, tão popularizada nas décadas a partir da década de 1970. Segundo Sanchez e Schimitt (2016, p. 10) há diferenças entre moda unissex e moda sem gênero, trazendo a seguinte ideia: "a moda unissex são projetadas para se ajustarem e favorecer homens e mulheres, sendo geralmente do guarda roupa masculino, de modelagem básica e sem apelo estético, já a moda sem gênero "trata-se de peças neutras, que fogem de estereótipos históricos e culturais, roupas que se desconectam também a antiga ideia de unissex".

\section{Para Schneid e Barreto:}

Moda sem gênero não é sobre um homem usar saia, é sobre romper com padrões sociais. Desta forma, neutralização de gênero não é uma tendência de moda, mesmo que algumas marcas tentem se aproveitar disto para lucrar. É um movimento natural que reflete mudanças importantes que vêm acontecendo na sociedade." (Schneid \& Barreto, 2016, p. 13)

Indo em direção aos conceitos vistos anteriormente, quando se observa as imagens de Moda sem gênero vistas nas postagens do Instagram tem-se que as imagens estão atreladas à alguma marca e geralmente as propostas do vestir mostram homens e mulheres usando a mesma roupa, não apenas relacionadas ao guarda roupa feminino como também do masculino. A figura 1 foi tirada a partir do Hashtag \#modasemgênero, aparecendo 23.291 publicações. Neste Hashtag (\#modasemgênero) as primeiras imagens são roupas consideradas como unissex de acordo com a definição dada por Sanchez e Schimitt (2016), no entanto também aparecem muitas peças relacionadas ao vestuário feminino, só que utilizada por homens. 
Figura 1 - Hashtag \# moda sem gênero tirada do Instagram

Fonte: Instagram.com, em 17.06.2019
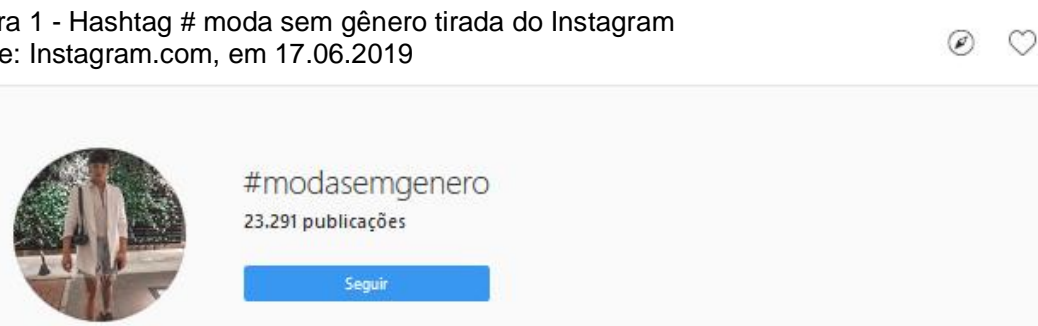

\#modasemgenero

23.291 publicaçōes
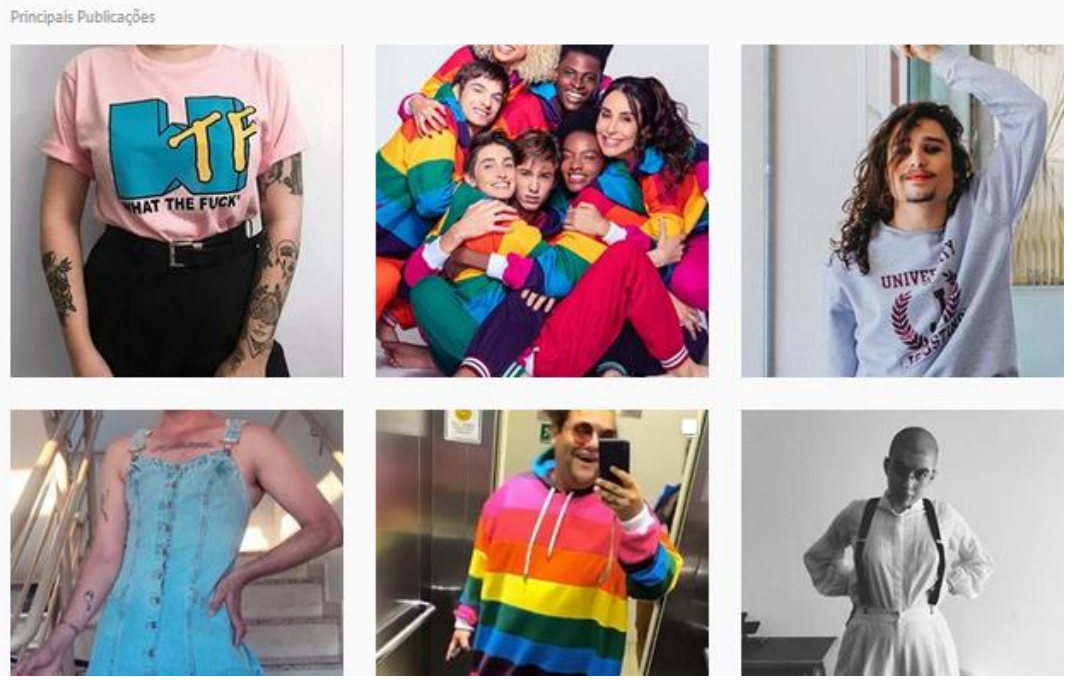

$\mathrm{Na}$ procura por outras publicações explorando a nomenclatura moda agênero, vê-se também peças originalmente de ambos os guarda roupas feminino e masculino, com 4.062 publicações (figura 2). Numa outra tentativa de se buscar palavras sinônimas relacionadas ao universo da moda com a expressão genderless tem-se 259.196 publicações, conforme a figura 3 , e também se referem a peças para ambos os sexos.

Figura 2- - Hashtag \# moda agênero tirada do Instagram Fonte: Instagram.com, em 17.06.2019
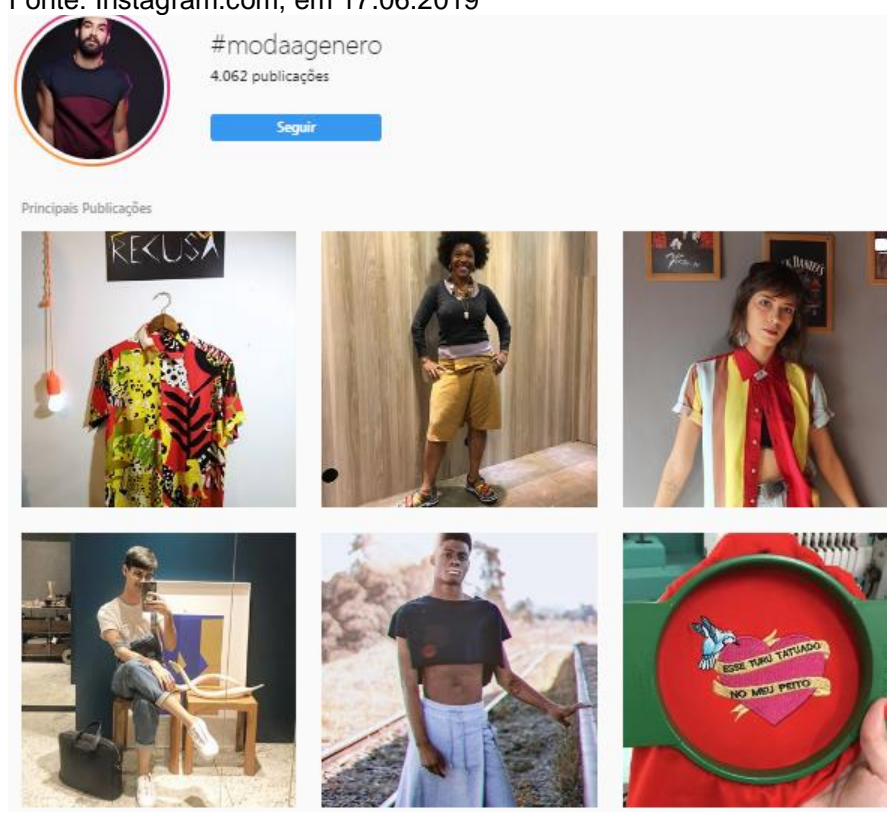
Figura 3- Hashtag \# moda genderless tirada do Instagram Fonte: Instagram.com, em 22.07.2019

의 | Instagram
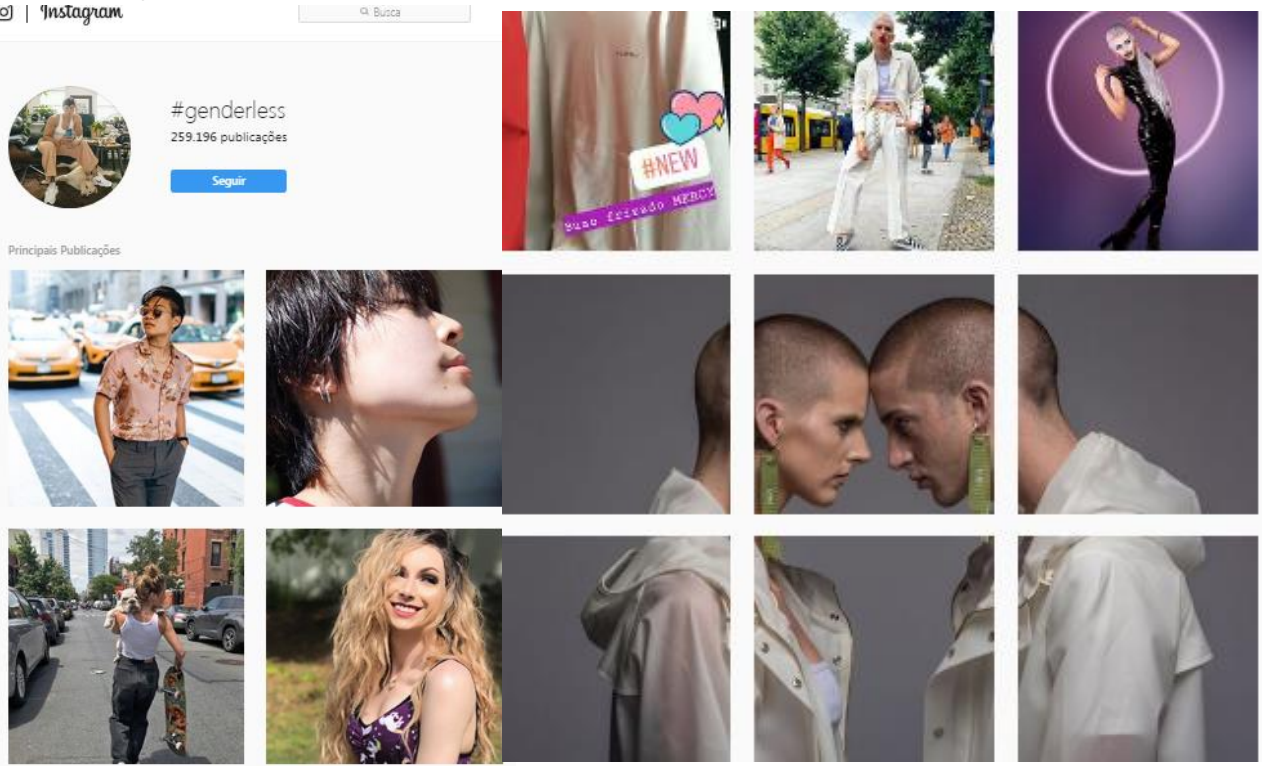

As publicações relacionadas acima apresentam um quadro sobre como os sujeitos e marcas de moda estão ressignificando a moda sem gênero. A proposta de algumas marcas de moda está em criar peças do vestuário que não tenham gênero, que qualquer pessoa possa comprar e usar sem categoriza-las em masculinas e femininas, com o discurso de que as roupas não têm gênero.

Ao entrar na segunda imagem da figura 1, tem-se a seguinte imagem (figura 4) indicando informações relacionadas à mesma dando ênfase a algumas palavras como "moda sem gênero, diversidade, arco-íris, oversized, não ao preconceito, dentre outras.

Figura 4- Campanha da marca " Você simples assim"- Moda sem gênero

Fonte: Instagram.com, em 17.06.2019
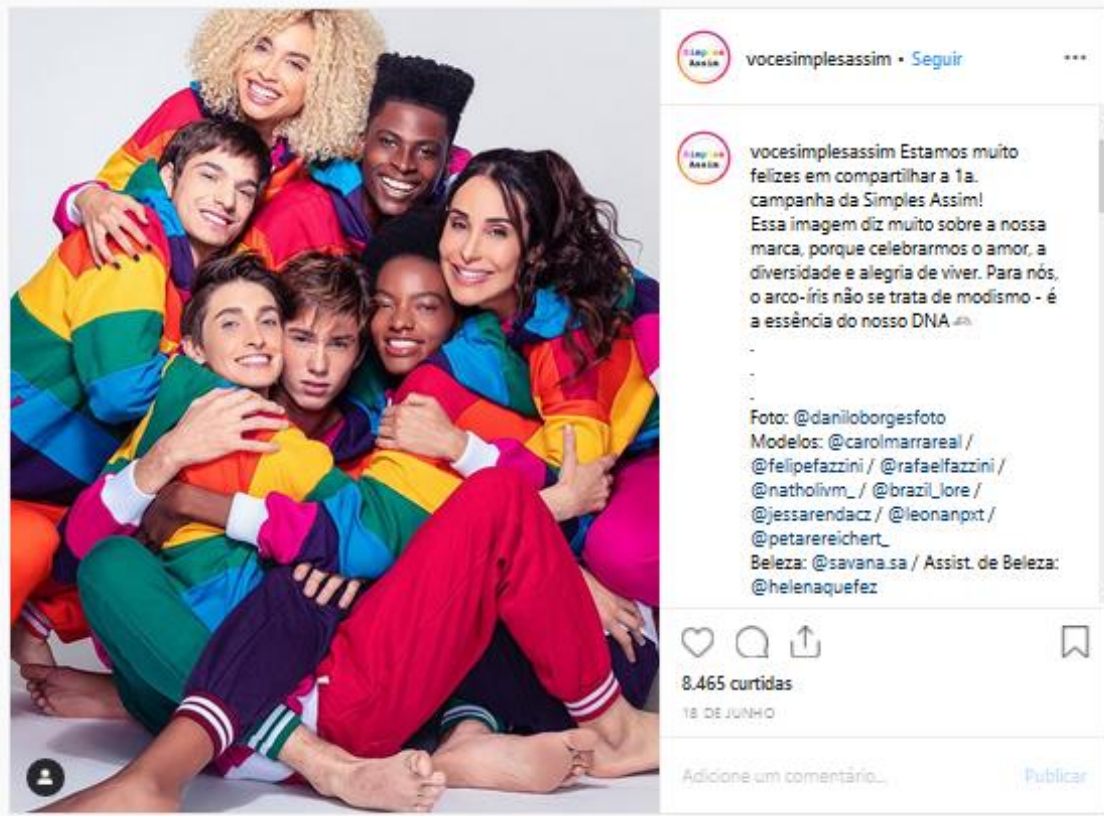

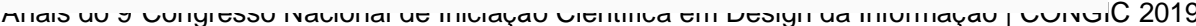

Proceedings of the $9^{\text {th }}$ Information Design Student Conference 
A imagem acima (figura 4) apresenta vários sujeitos com peles e cabelos diversos, onde seus corpos não são evidenciados, utilizando a mesma roupa, coloridas e folgadas com o seguinte discurso: "Essa imagem diz muito sobre a nossa marca, porque celebramos o amor, a diversidade e a alegria de viver, para nós o arco-íris não se trata de modismo, é essência do nosso DNA". Observa-se com o número de curtidas a aceitação desta imagem e mensagem, com 8.465 curtidas.

Figura 5- Campanha da marca " Você simples assim"- Moda sem gênero -Fonte: Instagram.com, em 17.06.2019
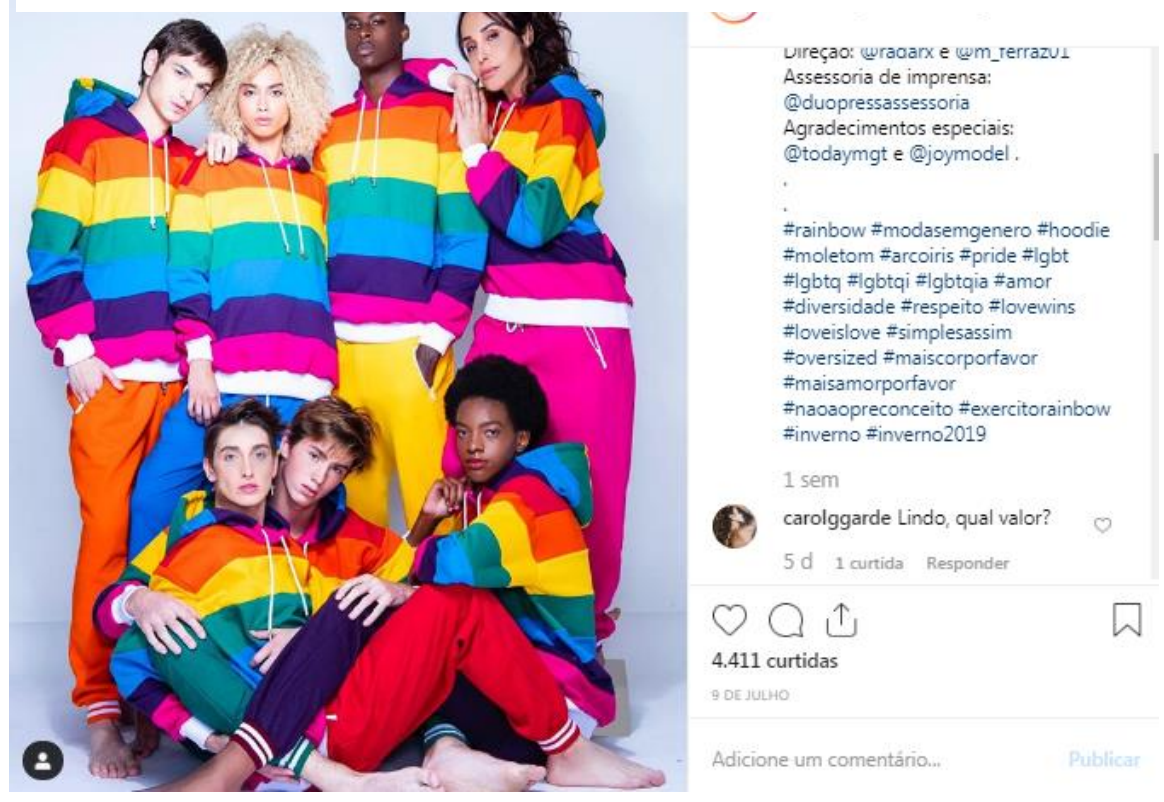

Figura 5a- Comentários dos seguidores do Instagram da Campanha da marca " Você simples assim"- Moda sem gênero

Fonte: Instagram.com, em 17.06.2019

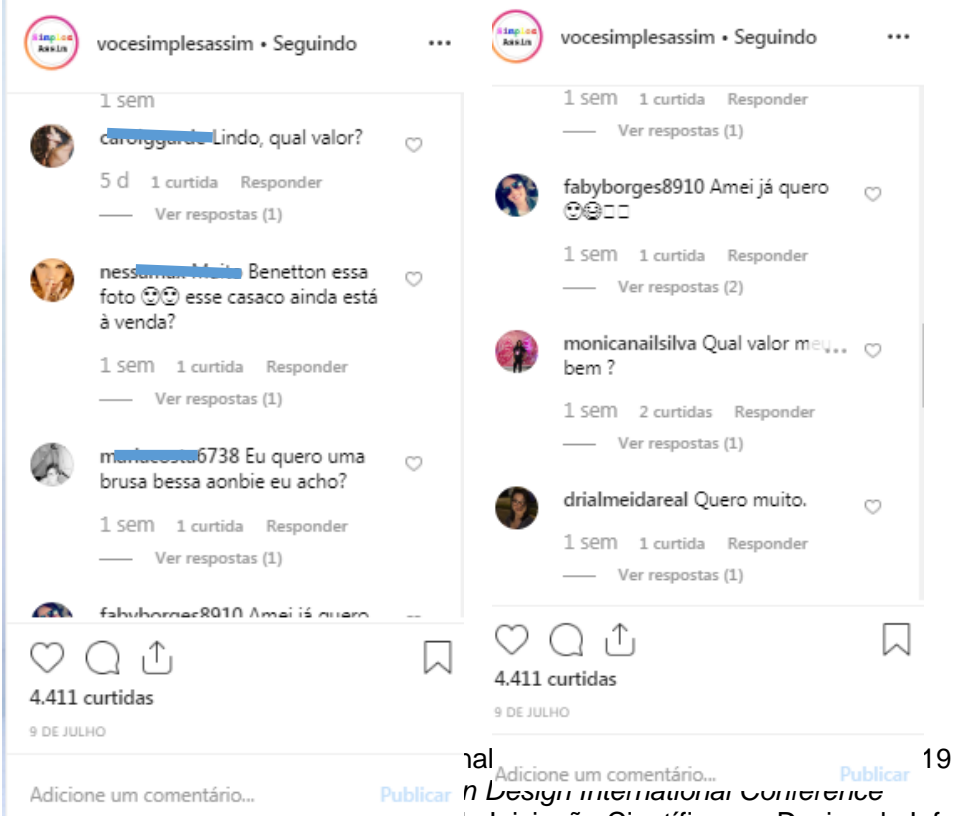

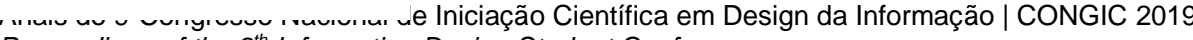

Proceedings of the $9^{\text {th }}$ Information Design Student Conference 
Os comentários realizados pelos usuários ou pessoas interessadas na marca acima (figura 5a) mostram o quanto estas peças são bem aceitas pelos mesmos, lembrando inclusive da campanha da moda Unissex da marca Benneton na década de 1980.

Alguns discursos atrelados à imagem da marca são criticados por alguns teóricos, como por exemplo, Portinari, Coutinho e Oliveira (2019) pontuam que a reinvindicação queer é a base teórica observada socialmente e que as marcas de moda a colocam "rasamente" em seus conceitos de moda agênero, trazendo uma interrogação sobre a apropriação que a moda faz de um estilo "antimoda" transformando a ideia inicial ao qual foram criados como estratégia de marketing, para ampliar as possibilidades de mercado.

No entanto, é importante ressaltar que através das redes sociais, existe uma relação mais próxima entre a marca e seu público, havendo uma troca simbólica nesta interação. Conforme observam Demezio et al (2016, p. 4):

As Redes Sociais são plataformas onde seus usuários tem liberdade de publicar o que quiserem, quando e para quem quiserem. Ou seja, as Redes Sociais são basicamente um espaço onde as pessoas podem expressar suas opiniões e aprender sobre as capacidades e preferencias das outras pessoas.

Neste sentido, os sujeitos usuários da marca através da aceitação ou rejeição das propostas dadas constroem uma relação mais próxima com a marca, e assim, vão dando significados e ressignificados conceitos e ideias antigas, e neste caso especificamente da moda sem gênero, construindo juntos um discurso de moda.

Observa-se na imagem (figura 6), o termo não binário, fora das propostas hegemônicas de gênero, entrando nos conceitos de algumas marcas de Moda indo de encontro às teorias de gênero proposta por Judith Butler.

Figura 6- Conceito dado a Moda sem gênero (agênero) dado por uma consultora de imagem Fonte: Instagram.com, em 17.06.2019
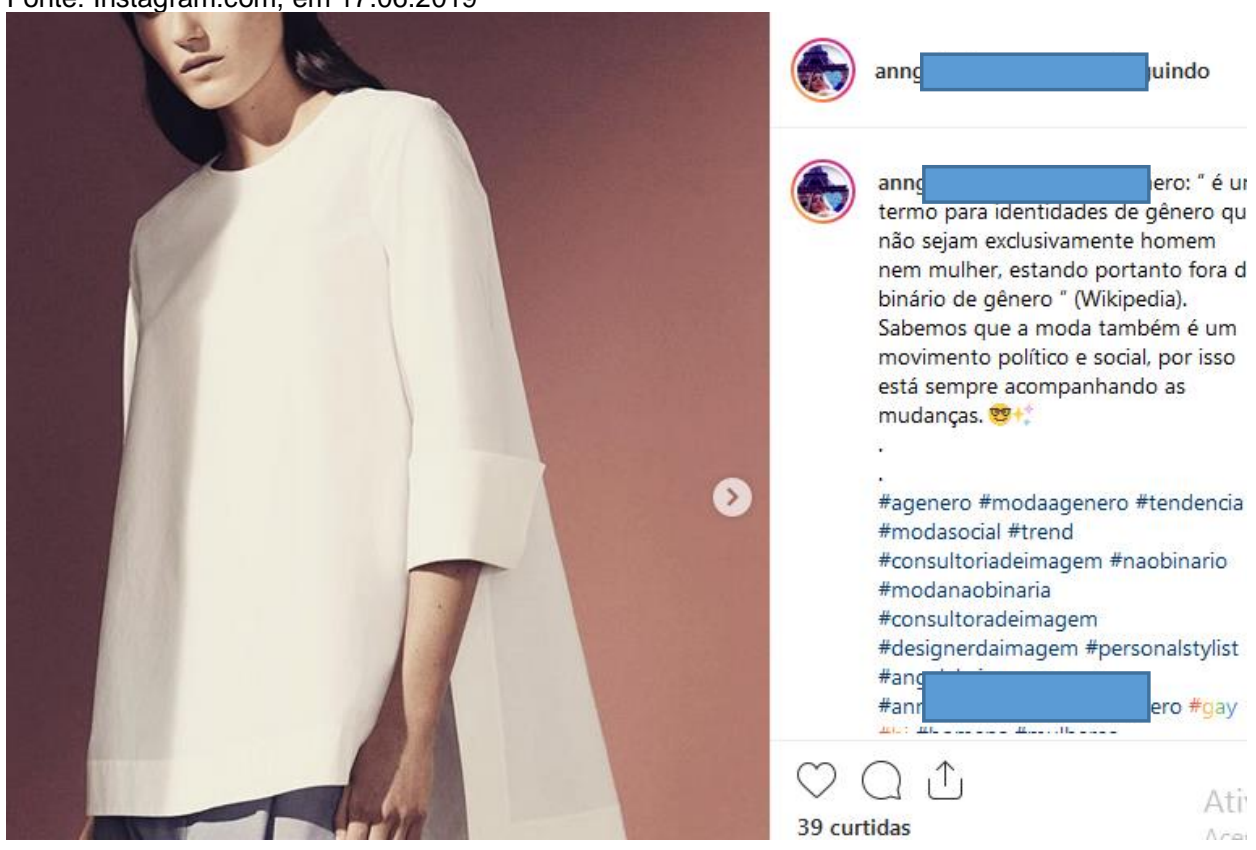

Ao lado da imagem da figura 6, ressalta-se a expressão Moda sem gênero como uma "moda social" onde existe a preocupação de enfatizar o movimento político de gênero que vêm 
acontecendo e o sistema de moda nas mídias sociais contribuindo com esta disseminação. $\mathrm{O}$ vestuário representado apresenta modelagem folgada, cor neutra (branca) utilizando uma calça de alfaiataria, que é culturalmente associada ao vestuário masculino. Uma das palavras destacadas estão em "moda não binária ", "hetero", "gay", colocando a roupa à disposição de todos, independentes de seu gênero.

Na figura 7 são destacados as hashtags camisaria, diversidade, genderless, inclusão, moda sem gênero, macacão, etc. Apresentam dois modelos: uma figura feminina e outra masculina utilizando um macacão, portanto a mesma peça foi ressignificada, onde a figura feminina utiliza um cinto de tecido deixando o corpo acinturado e os bolsos apresentam cores diferenciadas. A cor marrom do macacão é uma cor neutra que não é tradicionalmente atribuída a nenhum dos gêneros binários. Observa-se que são modelagens iguais pelo volume das peças, apresentando corpos diferentes no mesmo vestuário, a mulher utiliza o calçado preto enquanto o homem está descalço.

Figura 7- Moda sem gênero marca de moda Lepatstyle
Fonte: instagram.com , em 17.06.2019
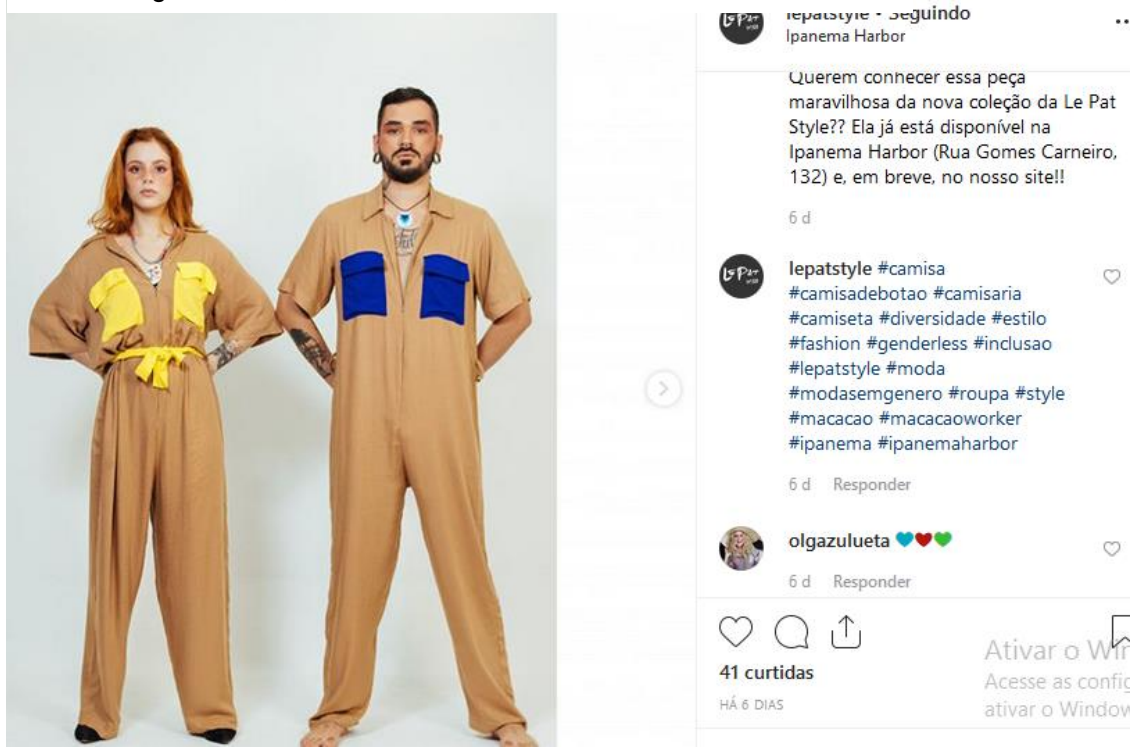

A imagem parece ter sido revisitada ao conceito proposto pela moda Unissex, portanto esta proposta do vestir como moda sem gênero ao mesmo tempo que dissemina a ideia central de vestir quaisquer corpos, também pode esvaziar este movimento, que Portinari; Coutinho e Oliveira (2018) colocam a expressão gentreficação (domesticação, perda do potencial crítico) próprio da moda, onde ao longo da história tem-se o movimento hippy, punk e etc, que foram surgidos nas ruas, e que a moda apropriou-se para então popularizar e se esvaziar em seus conceitos principais. Por outro lado, são reflexos sobre as mudanças e resistências em torno deste tema e que ainda vem ganhando novos simbolismos e valores.

Schneid e Barreto (2016) traz uma reflexão sobre a "feminização" do vestuário masculino e "masculinização" do vestuário feminino ao longo da história da moda e colocam as apropriações referentes ao vestuário feminino, principalmente pelo público masculino, já que as mulheres transitam entre o vestuário masculino e feminino naturalmente, portanto o inverso é visto com muito preconceito.

A imagem abaixo (figura 8) destaca um pouco da história da moda, onde Chanel se apropriou do vestuário masculino para compor seu look, disseminando esta nova proposta de moda. E as palavras destacadas referem-se a moda sem gênero, uma moda "para ele e para ela". Esta imagem vai contra ao que Butler destaca em sua teoria da perfomatividade, pois a proposta se coloca como moda sem gênero, mas coloca a binaridade Ele e Ela (masculino e feminino), o que não reflete os problemas de gênero trazida por Butler. 
Figura 8- Campanha da revista "Glam" sobre moda sem gênero Fonte: instagram.com , em 17.06.2019
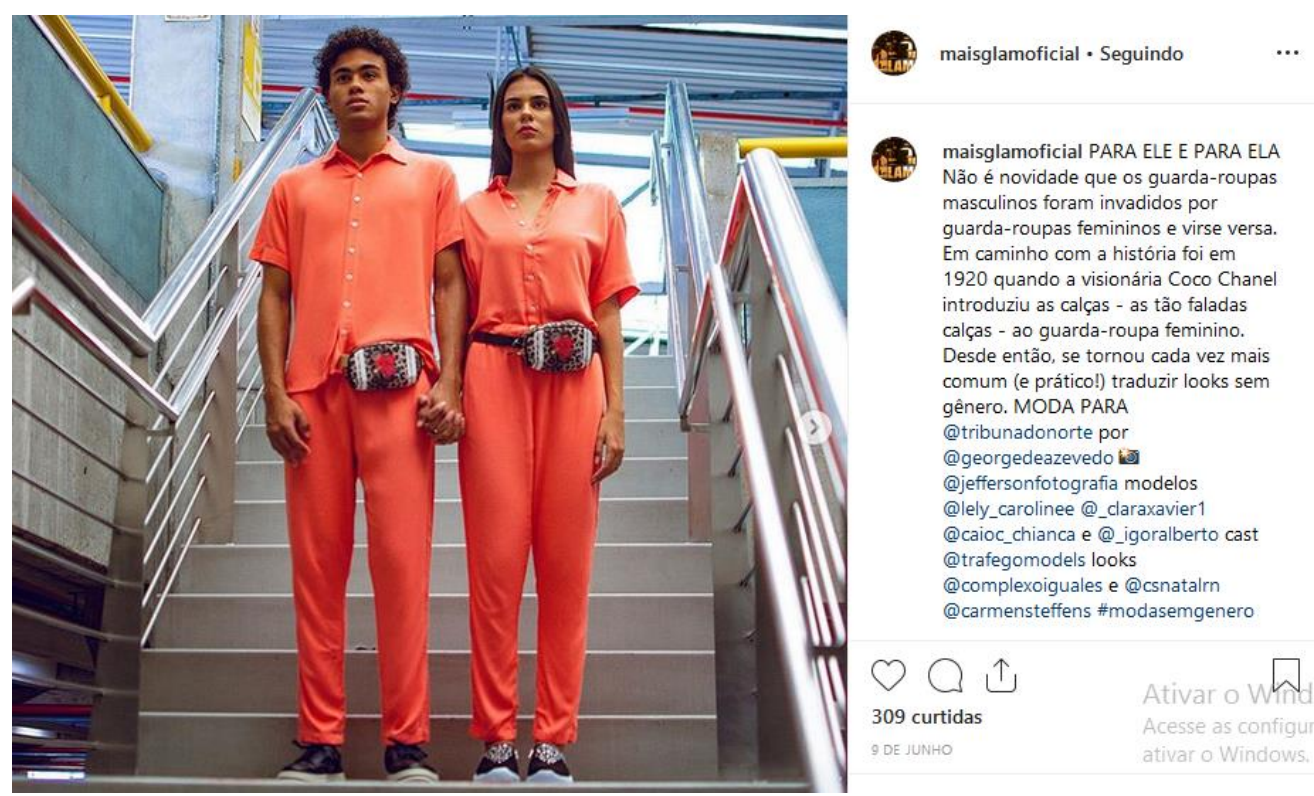

As imagens das figuras 7 e 8 , se enquadra mais na proposta da moda Unissex, trazendo a mesma peça do vestuário para ambos os gêneros e os próprios modelos são representados com atributos tradicionais de ambos os gêneros, como mulheres de cabelos compridos, corpos femininos e corpos masculinos, além da cintura marcada feminina. Desta forma, tem-se um pequeno panorama da representação que as marcas de moda fazem utilizando o conceito de moda sem gênero para atrair o olhar daqueles usuários que se interessam pelo conceito sem gênero. O número de curtidas destas imagens refletem a aceitação tanto da mensagem como da imagem. Assim como os comentários associados às mesmas (figura 8a).

Figura 8a- Cometários dos seguidores da campanha da revista "Glam" sobre moda sem gênero Fonte: instagram.com , em 17.06.2019

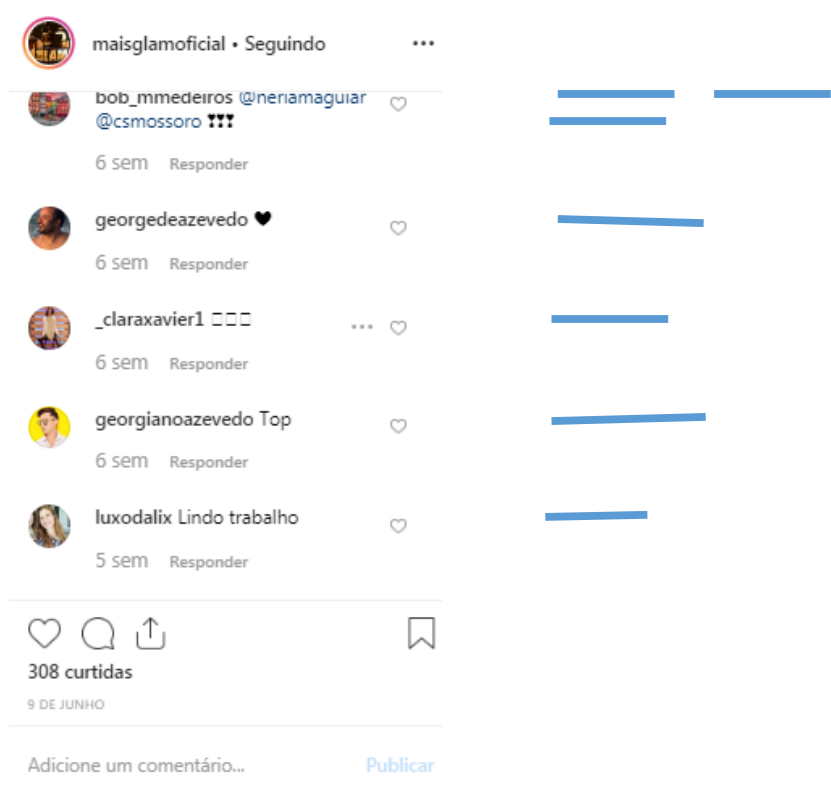

Anais do $9^{\circ}$ Congresso Nacional de Iniciação Científica em Design da Informação | CONGIC 2019

Proceedings of the $9^{\text {th }}$ Information Design Student Conference 
As imagens apresentadas acima representam uma pequena parte da representação da moda sem gênero e as narrativas em torno delas, nas descrições escritas por meio do hashtags e dos posts dos usuários. As marcas de moda apresentam interesses próprios de ampliar e atrair seu público, e mesmo que a teoria da performatividade nem seja conhecida por ambos, as marcas e os usuários, há uma reflexão em torno do assunto sexo, gênero, binaridade, não binaridade. Logo, a proposta do vestir sem gênero gera novas narrativas do vestir, para expressão da subjetividade, colocando sujeito como agente transformador das formas de se observar o gênero. Segundo Schneid e Barreto (2016, p. 13) " A moda passa a ser não apenas um retrato do nosso tempo, mas também um agente de inclusão e promoção da diversidade".

Embora estas imagens não representem a totalidade do discurso da moda sem gênero, mostram que através das redes sociais, em especial o Instagram é possível observar como a informação de moda sem gênero vem sendo difundida.

\section{Considerações Finais}

A teoria de gênero, proposta por Butler, aqui revisitada abre espaço para as discussões além do gênero, implicando questionamentos a partir da moda sem gênero, que é uma das formas de dar legitimidade ao próprio movimento, trazendo a atenção para a binaridade dos mesmos no sistema hegemônico heteronormativo.

Esta teoria da perfomartividade de Gênero, Teoria Quuer, considera o sexo e gênero um atributo cultural estabelecido desde o nascimento. Nota-se pelas imagens capturadas que a performatividade de gênero, estes atos repetitivos que dá legitimidade as crenças sobre as constituições das identidades de gênero, estão inseridos nestes discursos, portanto colocam alguns argumentos de transformação para inclusão das identidades «fora do contexto hegemômico"».

A moda sem gênero é uma reflexão no campo da moda que traz visibilidade para as questões de gênero, mesmo relacionada ao consumo e o sistema da moda, portanto, traz a atenção crítica sobre as roupas e a binaridade masculino $x$ feminino. No entanto embora a proposta esteja em adequar as roupas como moda sem gênero, algumas das imagens como a figura 7 e 8 apresentam a figura feminina e masculina utilizando as mesmas peças, o que não representa o conceito tratado como moda sem gênero, reforçando ainda mais a binaridade.

Tendo em vista a preocupação inicial do campo do design onde se propõe estudar objetos materiais e imateriais, a relação com os sujeitos, estes artefatos e a cultura, estas imagens mostram apenas um recorte da disseminação do conceito de moda sem gênero através da mídia social, e as informações colhidas e analisadas neste meio, geram bases para novas formas de pensar os gêneros refletindo nos objetos de design de moda, em especial.

No entanto, estas análises apresentadas anteriormente reforçam a preocupação dos indivíduos em não seguir veementemente as formas tradicionais do vestir e questionar as identidades de gênero de forma binária, e principalmente questionar porque homens e mulheres devem se vestir de formas diferentes, que existem linguagens visuais diferentes para cada gênero, como também enquadrar as roupas conforme o sexo biológico ou gênero estabelecido culturalmente.

\section{Referencias}

Butler, J. (2003). Problemas de gênero: Feminismo e subversão da identidade. Rio de Janeiro: Ed. Civilização Brasileira.

Carzola, A. V; Noronha, R. F. (2015). Além do look do dia: o aplicativo instagram e a moda contemporânea. In: $5^{\circ}$ ENP Moda -Encontro Nacional de Pesquisa em Mod).

Demezio, C.; Silva, D; Rodrigues, D.; Oliveira, G.; Barbosa, K., \& Melo, C.(2016) O Instagram como ferramenta de aproximação entre Marca e Consumidor. In: Intercom- Sociedade

Anais do 9² Congresso Internacional de Design da Informação |CIDI 2019

Proceedings of the 9th Information Design International Conference

Anais do $9^{\circ}$ Congresso Nacional de Iniciação Científica em Design da Informação | CONGIC 2019

Proceedings of the $9^{\text {th }}$ Information Design Student Conference 
Leite, I. T. R. \& Waechter, H. | A informação de moda sem gênero nas mídias sociais: o sujeito contemporâneo enquanto agente no processo de construção do vestuário

Brasileira de estudos interdisciplinares de comunicação, XVIII Congresso de ciência da comunicação da região nordeste- Caruaru-PE.

Portinari, D. B., Coutinho, F. R., \& Oliveira, J. M. da Silva.(2018). Moda agênero: uma proposta de moda que desconstrói as fronteiras de gênero (2018). Revista Dobras. São Paulo: Estação das letras e cores.

Sanches, G; Schmitt, J. (2016) Moda sem gênero; conceituação e contextualização das tendências não binárias. In: $12^{\circ}$ Colóquio de Moda - 9ª Edição Internacional.

Salih, S. (2015). Judith Butler e a Teoria Queer.; tradução e notas Guacira Lopes Louro. - 1. ed.; 3. reimp. - Belo Horizonte : Autêntica Editora.

Silva Jacilene.(2018). Identidade de gênero: os atos performáticos de gênero segundo Judith Butler. Recife: Independently published. Kindle.

Zambrini, L. (2016). Olhares sobre moda e design a partir de uma perspectiva de gênero. Revista Dobras, Junho- volume 19. São Paulo :Estação das letras e cores.

\section{Sobre o(a/s) autor(a/es)}

Iracema Tatiana Ribeiro Leite, Doutoranda, UFPE, Brasil <tatrleite@gmail.com>

Hans Wacther, Doutor, UFPE, Brasil <hnwaechter@terra.com,br> 